\title{
Hajdučija u Hercegovini u 18. stoljeću
}

Dijana PinJuh

Sveučilište u Mostaru

Filozofski fakultet

E-pošta: dijana.pinjuh@ff.sum.ba
UDK: 94(497.6 Hercegovina)"17"

Izvorni znanstveni rad

Primljeno: 26. svibnja 2018.

Prihvaćeno: 9. travnja 2019.

\section{Sažetak}

Samovolja lokalnih moćnika koja je tijekom 18. stoljeća sve više dolazila do izražaja, sukobi s vanjskim silama, porast redovitih i izvanrednih nameta te zlouporabe vladajućih struktura sve više ugrožavaju socijalni položaj stanovništva. Porezni i feudalni pritisak povećavao je odmetanje u hajduke, a pljačke, razbojstva i druga zlodjela postala su dio svakodnevice. Mjere koje su poduzimale osmanske vlasti nisu imale učinka, a hajdučke su družine svojim djelovanjem tijekom cijeloga stoljeća unosile nemir i prijetile sigurnosti. Podršku i zaštitu nalazili su među svojim jatacima, kojima je jednako kao i hajducima prijetilo kažnjavanje zbog učinjenoga. Raznovrsnu građu o zbivanjima u 18. stoljeću i hajdučiji na prostoru Hercegovine daju objavljeni i neobjavljeni sudski zapisnici (sidžili) na temelju kojih će se dati jedna jasnija i potpunija slika o hajducima i njihovom djelovanju.

Ključne riječi: hajduci; 18. stoljeće; Hercegovina; jataci; hajdučko djelovanje. 


\section{Uvod}

Izraz hajduk (hajdúk, haydud, haydut), kojim se redovito označavaju razbojnici u balkanskim pokrajinama Osmanskoga Carstva, potječe od mađarskog hajdu, što znači naoružani vojnik, profesionalni plaćenik bez zemlje. Ista se riječ sa sličnim značenjem javlja u Poljskoj, Ukrajini i Češkoj, ali se za Južne Slavene značenje riječi hajduk u prvom redu odnosilo na "bandits who acted as protectors of Christians against Ottoman oppression". ${ }^{1}$ Međutim, hajdučija kao pojava nije osmanski produkt. Ona je na prostoru jugoistočne Europe bila poznata stoljećima prije dolaska Osmanlija, još od vremena Ilira. ${ }^{2}$ Potaknuta socijalnim previranjima ili političkim okolnostima vremenom će se razvijati i oblikovati, ali će do kraja svoga postojanja zadržati izvorni cilj, a to su pljačka i razbojstva. Hajdučija kao kompleksna pojava ne može se smjestiti na jedan ograničen prostor, niti se može vezati za određenu društvenu ili vjersku skupinu. Uglavnom je nastajala kao odgovor na teške socijalne uvjete, a jednako su joj pristupali kršćanski i muslimanski podanici. Pljačka je bila i ostala osnovni izvor prihoda, a plijen do kojega su dolazili pljačkanjem osnovni izvor preživljavanja.

Prepadi i pljačke razbojničkih skupina na prostoru Hercegovine mjestimice se javljaju već početkom 14 . stoljeća. Takve su akcije uglavnom uključivale oduzimanje stoke ili hrane, te trgovačke robe. Krajem stoljeća pljačke će postati češće i postupno će prijeći u profesionalnu hajdučiju, koja će s dolaskom Osmanlija poprimiti jedan sasvim novi oblik. ${ }^{3}$ Porast redovitih i izvanrednih nameta, te brojnih zlouporaba vladajućih struktura nauštrb raje sve je više utjecalo na odmetanje seljaka u hajduke, tako da će upravo u osmanskom razdoblju hajdučija doseći svoj najveći zamah. Pogoršanje životnih uvjeta utjecalo je na pojačane hajdučke prepade, kojih nije bilo pošteđeno ni kršćansko stanovništvo. Osim pljačkaških akcija aktivno su sudjelovali i u

1 Encyclopedia of the Ottoman Empire, Gábor Ágoston Georgetown University, Washington, D. C. Bruce Masters Wesleyan University, Facts On File, Inc. An imprint of Infobase Publishing, 2009., str. 252.

2 Nakon sloma Velikoga ilirskog ustanka 9. godine poslije Krista, hajdučke skupine proistekle iz razbijenih ostataka ustanika nastavile su djelovati i pružati otpor rimskoj vlasti. Više o hajdučkoj aktivnosti u ilirskim pokrajinama u: Salmedin Mesinović, "Hajdučija na tlu rimskih ilirskih provincija", u: Prilo$z i, 38$, Sarajevo, 2009., str. 31-39.

3 Bogumil Hrabak, "Hajdučija u Bosni i Hercegovini do 1700. godine", u: Iz starije prošlosti Bosne i Hercegovine, knj. V., Beograd, 2008., str. 288-302. 
ratovima za oslobođenje od osmanske vlasti, zbog čega su hajduci i hajdučke vođe često idealizirani kao borci za oslobođenje, heroji koji se stavljaju u službu potlačene raje a protiv omražene osmanske vlasti. Međutim, stvarnost je bila daleko od predstavljenoga. ${ }^{4}$

Izuzmemo li autore koji su o hajdučiji i hajducima pisali u sklopu književnih uradaka, vrlo je malo stručne literature koja objektivno prilazi toj problematici. Najveći znanstveni doprinos istraživanju hajdučije na prostoru Hercegovine dao je Bogumil Hrabak, koji je na temelju dubrovačke arhivske građe detaljno obradio djelovanje hajduka od 15. do početka 18. stoljeća. ${ }^{5}$ Hrabak je po pitanju haj-

4 Tijekom Kandijskoga (1645. - 1669.) i Bečkoga rata (1683. - 1699.) hajduci su u mletačkoj službi pod vodstvom svojih harambaša aktivno sudjelovali u ratnim sukobima. U tim su akcijama jednako napadali muslimansko i nemuslimansko stanovništvo, robili, palili i odvodili u ropstvo. O njihovu djelovanju u vrijeme ovih ratova više u: "Šilobadovićeva kronika", u: JosıP AnTE Soldo (prir.), Makarski ljetopisi 17. i 18. stoljeća, Književni krug, Split, 1993., str. 1568. Zbog hajdučkih provala i pustošenja na prostoru Trebinjsko-mrkanske biskupije u drugoj polovici 17. stoljeća mnoga su mjesta ostala uništena i bez stanovnika. Hajduci su mnoge katolike odvodili u ropstvo i prodavali u Napulj, Veneciju ili Đenovu, a u strahu od hajduka stanovništvo je bježalo iz najugroženijih područja. O hajdučkom pustošenju i štetama koje su hajduci svojim provalama nanosili kršćanskom stanovništvu više u izvješćima biskupa i svećenika u: Marko Jačov, Le missioni cattoliche nei Balcani durante la guerra di Candia (1645 - 1669), vol. II., Studi e testi 353, Biblioteca apostolica Vaticana, Vaticano, 1992., str. 412, 418, 446-447, 449-450, 482-484, 504-505, 678. Također vidi: Acta franciscana Hercegovinae, sv. I., str. 452-453, 454-455. Prilikom jedne provale u Popovo 1692. godine, hajduci su ubili župnika Iliju Boškovića. Biskup Primović o tome događaju bilježi sljedeće: "Razlog zbog kojeg su ubili ovog nevinog svećenika bio je samo taj što je on držao u kršćanskom zakonu one ljude. Hajduci su mislili da bi se oni kršćani, kad bi bili bez duhovne pomoći, odmetnuli od Turaka i prešli k njima. To ih je potaknulo na ovo opako i bezbožno djelo". Originalan tekst i prijevod donosi BAzıLIje PANDžIĆ, "Trebinjska biskupija u tursko doba", u: IvicA PuljIĆ (prir.), Tisuću godina Trebinjske biskupije, Sarajevo, 1988., str. 103, bilj. 108.

5 Bogumil Hrabak na temelju dubrovačke arhivske građe između ostalih pitanja istraživao je i pitanje hajdučije, rezultat čega su i njegovi radovi: "Hajdučija Hercegovaca 1465. - 1530.", u: Oslobodilački pokreti jugoslavenskih naroda od XVI. veka do početka Prvog svetskog rata, Beograd, 1976., str. 11-26; IsTI, "Trebinje, Popovo i Donja Neretva u hajdučkom vojevanju za vreme Morejskog rata", u: Prilozi Instituta za istoriju, XVII., Sarajevo, 1980., str. 69-99; IsTI, "Hajdučija u Bosni i Hercegovini do 1700. godine", u: Iz starije prošlosti Bosne i Hercegovine, knj. V., Beograd, 2008., str. 282-335; Isti, "Zlići iz Herceg-Novog i zulućarenje na račun dubrovačke trgovine (1600 - 1687)", u: Iz starije prošlosti Bosne i Hercegovine, knj. V., Arhivar Beograd, Beograd, 2008., str. 335-380. 
dučije otišao najdalje istražujući njezin postanak te razlikujući je po mjestu i načinu djelovanja. Tako razlikuje drumsku, plemensku i pograničnu hajdučiju, razbojničko zaustavljanje, te gradsku mafiju kao posljedicu doseljavanja muslimanskoga stanovništva u gradove koje nije imalo osiguranu egzistenciju, a od kraja 17. stoljeća javlja se i nacionalna hajdučija. ${ }^{6}$

Osim Hrabaka treba spomenuti i Vesnu Miović-Perić, ${ }^{7}$ Šimu Peričića ${ }^{8}$ te u novije vrijeme Mariju Kocić ${ }^{9}$ i Fuada Ohranovića ${ }^{10}$ koji su, svaki za određeno područje i razdoblje, pridonijeli stvaranju jasnije slike o hajdučkom djelovanju. Ovdje će se na temelju sudskih zapisa (sidžila) iz 18. stoljeća također dati jedna jasnija slika o hajdučkom djelovanju na prostoru Hercegovine, odnosno onih dijelova koji su u tom razdoblju bili u djelokrugu mostarskoga, blagajskoga i nevesinjskoga kadije. ${ }^{11}$ Kako su ovdje obrađeni sidžili samo djelomično saču-

6 B. Hrabak, "Hajdučija u Bosni i Hercegovini...", str. 284-287.

7 Vesna Miović-Perić, Na razmeđu (odnosi na dubrovačko-osmanskoj granici 1667. - 1806.), Zavod za povijesne znanosti HAZU, Dubrovnik, 1997.; Ista, "Brigandage on the Ragusan Frontier during the Morean War (1694 1699)", u: Dubrovnik Annals, 3, 1999., str. 41-54.

8 Šme Peričić, "Hajdučija u mletačkoj Dalmaciji tijekom XVIII. stoljeća", u: Rad Zavoda za povijesne znanosti HAZU u Zadru, sv. 41, 1999., Zadar, str. 203-212.

9 Marija Kocić, Venecija i hajduci u doba Morejskog rata, HESPERIAedu Naučno društvo za istoriju zdravstvene kulture, Beograd, 2013. Kocić je također autorica studije o muslimanskim novskim "zlićima", "Alaga Šabanović i Omer-aga Begzadić kao predstavnici prve generacije novskih 'zlića'", str. 151-168. Clanak na ćirilici dostupan na Academia.edu, ali bez potpunih bibliografskih podataka. https://www.academia.edu/31210347/Марија_Коцић_ Алага_Шабановић_и_Омерага_Бегзадић_као_представници_прве_ генерације_новских_злића_(23.4.2018.).

10 Fuad Ohranović, "Sigurnosna situacija u Hercegovačkom sandžaku tokom prve polovine XVII stoljeća", u: Prilozi za orijentalnu filologiju (dalje: POF), 64, Orijentalni institut, Sarajevo, 2015., str. 255-277.

11 Fotokopije neobjavljenih sidžila korištenih u radu nalaze se u Arhivu Hercegovine Mostar, zavedene u inventaru Acta turcarum pod brojevima XXIII/1121, XXIII/1123, XXIII/1124, XXIII/1125, XXIII/1127. Četiri fotokopije nisu označene brojevima. Originali fotokopija nalaze se u Orijentalnom institutu Sarajevo i zavedeni su u Inventar službenih knjiga pod brojevima 56, 57, $58,59,60,61$, s izuzetkom jednoga koji se nalazi u privatnom posjedu. Za dvije fotokopije koje su zavedene u Arhiv nema podataka o originalnom rukopisu. Sve prijevode načinio je Hivzija Hasandedić, arhivist Arhiva Hercegovine. Autorica zahvaljuje Zijadu Goliću i njegovim kolegama, djelatnicima Arhiva Hercegovine, na pomoći u prikupljanju građe. 
vani, kao i većina sidžila iz ovoga razdoblja, pojedine je događaje bilo teško rekonstruirati ili pratiti u kontinuitetu. Zbog fragmentarnosti dokumenata ne će se ulaziti u detaljniju analizu vrsta hajdučije, koje se uočavaju i u ovdje obrađenim dokumentima.

U sudskim zapisima osim hajduka često se spominju i odmetnici, koji također po putovima presreću putnike i pljačkaju ih, jednako kao i hajduci, što se može pripisati vrstama hajdučije koje spominje Hrabak. Ipak, pojedini zapisi jasno razdvajaju hajduke od odmetnika, iako su i hajduci odmetnici od vlasti. Izdvajamo primjer bosanskoga namjesnika Hekimoglu Ali-paše, koji u jednoj naredbi iz 1747. godine koju prenosi Muhamed Hadžijahić navodi kako u proljeće "odmetnici zauzmu određene položaje u šumama i kao hajduci napadaju putnike i plijene njihovu robu". ${ }^{12}$ Pod odmetnicima su se podrazumijevali svi oni koji su na bilo koji način iskazivali svoje neslaganje sa zlouporabama vladajućih struktura, bilo da se radi o kršćanima ili muslimanima. Ovdje će naglasak biti stavljen na hajduke, iako se često zbog društveno-političkih okolnosti i prirode njihova djelovanja nije moglo izbjeći i spominjanje odmetnika. Također je potrebno istaknuti da će se rad baviti hercegovačkim a ne crnogorskim hajducima, koji su često djelovali na pograničnim dijelovima i u datim okolnostima čak uzbunjivali raju protiv osmanske vlasti i na prostoru Hercegovine. Zbog brojnosti dokumenata koji donose podatke o crnogorskim hajducima i njihovu djelovanju, smatramo da je tu problematiku bolje razraditi u zasebnoj studiji.

\section{Pregled prilika u 18. stoljeću}

Višegodišnji sukob kršćanskih zemalja protiv Osmanskoga Carstva, započet pod Bečom 1683., dobit će svoj epilog potpisivanjem mira u Srijemskim Karlovcima 1699. godine. Osim Moreje, Osmansko je Carstvo izgubilo i velike dijelove teritorija koji su se ranije nalazili u Bosanskom i Budimskom ejaletu, koji je još 1686. prestao postojati. Bosanski ejalet, kao najzapadnija pokrajina Osmanskoga Carstva, našao se u nezavidnom položaju, a sav teret osiguranja graničnoga područja pao je na leđa stanovništva i lokalnih zapovjednika. Napetosti na granici koje su trajale od potpisivanja mira kulminirat će u novom mletačko-osmanskom ratu (1714. - 1718.) koje će Osmansko Carstvo koštati gubitka novih teritorija. U razdoblju koje

12 Muhamed Hadžijahić, "Bune i ustanak u Bosni sredinom XVIII stoljeća", u: Historijski zbornik, god. XXXIII-XXXIV (1), Zagreb, 1980. - 1981., str. 105. 
će uslijediti nakon Požarevačkoga mira (1718.), a koje je u osmanskoj historiografiji ostalo zabilježeno pod nazivom "Doba tulipana" (1718. - 1730.), Osmanlije će napustiti osvajačku politiku, i okrenuti se kulturnom, umjetničkom i tehničkom razvoju pod utjecajem Zapada. U isto vrijeme zlouporabe vladajućih struktura na prostoru Hercegovačkoga sandžaka sve više dolaze do izražaja. Porezi i podavanja koje je država zbog financijskih teškoća morala povećavati bili su velik teret za narod. Zakupnici poreza i državnih prihoda bili su većinom iz redova lokalnih moćnika, što je otvaralo prostor za brojne zlouporabe i nepravde nauštrb raje. Raja je pravdu i zaštitu od nasilja tražila na Porti, ali središnjica nije uspijevala zaštititi najsiromašnije. Sve se uglavnom svodilo na dopise u kojima se odgovorne podsjećalo da raju, kao i sve stanovništvo, moraju štititi od nasilja. Međutim, pokrajinska uprava nije previše marila za naređenja s Porte, koja konkretne mjere protiv zlouporaba nije poduzimala. Nasilnici iz vladajućih redova rijetko su ili nikako kažnjavani. To pokazuje i slučaj spahije Murata Velagića, protiv kojega je bosanski valija u više navrata slao naređenja o njegovu hapšenju. Spahiju i druge prijestupnike poimence: Huseina Semšića iz Rotimlje, Saliha Boškajla iz Hodova te Mahmuda Husamovića, teretilo se da su 1728. nagovarali narod da ne daje traženu pomoć za izgradnju sarajevske tvrđave. Unatoč tomu, bosanski valija Ahmed-paša naređuje da se spomenutome spahiji i drugim navedenim prijestupnicima "oproste raniji grijesi" te da ih više nitko ne uznemirava i napada, jer su se kasnije pokorili šerijatu. ${ }^{13}$ Prijestup nije pripadao u kategoriju teških zlodjela, a i činjenica da su se pokajali za učinjeno vjerojatno je utjecala na takvu odluku.

Zlouporabe koje su činili Ahmed-paša i njegov sin Rustem-paša bile su daleko ozbiljnije i teže su pogađale raju od ovoga što je činio spahija Murat. Protiv valije Ahmed-paše (namjesnik Hercegovine 1727., zatim namjesnik Bosne od 1727. do 1730.) i njegova sina Rustem-paše, koji je $\mathrm{u}$ isto vrijeme bio namjesnik Hercegovačkoga sandžaka, upućena je pritužba na Portu u kojoj se tvrdi kako otac i sin čine razna

13 Bosanski valija Ahmed-paša džumada I 1141. (prosinac 1728.) šalje bujuruldiju blagajskom kadiji, kapetanu Počitelja, agama nefera, dizdaru mustahfiza blagajske tvrđave, mustahfizima i ostalim neferima kojom im još jednom naređuje da se izvrši hapšenje spomenutoga spahije i drugih neimenovanih odmetnika. U bujuruldiji nije navedeno o kakvim se prijestupima radilo, ali se u bujuruldiji od 25. rebia II 1142. (studeni 1729.) upućenoj blagajskom naibu to jasno navodi. Sidžil blagajskog kadije 1728. - 1732. (regesta), obradio Hivzija Hasandedić, Islamski kulturni centar, Mostar, 2009., str. 33, 36. 
nasilja agama, vojnicima i stanovnicima sela, bespravno prikupljaju novac, neke kapetane i čuvare granica nezakonito globe ili ubijaju. Osim toga, "traže i prikupljaju novac pod izgovorom da se podižu tvrđave u Sarajevu, Glamoču i Podzvizdu". Njihovo ponašanje bilo je uzrokom bježanja raje na kršćanski teritorij, zbog čega sultan fermanom, odnosno pismenom naredbom od šabana 1143. (veljača 1731.) naređuje tadašnjem valiji Osman-paši da se uhvate ćehaje optuženih, oduzme sve što su bespravno oduzeli i kazne. ${ }^{14}$ Slijedom naredbe Osman-paša je bujuruldijom od 2. zulhidžeta 1143. (lipanj 1731.) obavijestio kadije i kapetane od Mostara do Ključa i Klobuka, te zabiti (vojni zapovjednici) i age nefera (vojnika) o nasiljima bivšeg valije Ahmed-paše i njegova sina, te im naredio da se zbog protuzakonita potraživanja novca Ahmed-pašinog ćehaje, Ahmetage i kapidžibaše hadži Mustafe, a na temelju tužbe oštećene raje, vojnika i kapetana, navedeni uhvate i dovedu u Travnik. ${ }^{15}$ Iz dostupnih je dokumenata nejasno je li to uistinu i učinjeno, ali s obzirom na težinu optužbi može se pretpostaviti da su spomenuti privedeni na odgovornost.

Navedene tužbe protiv oca i sina nisu bile bez osnove. Rustem-paša u više je navrata tražio od stanovnika da se prikupe yemeklik ${ }^{16} \mathrm{i}$ saliyana ${ }^{17}$ za hercegovačkoga valiju, tj. za njega, a zastupnik njegova oca, kajmekam Ahmed-aga iste godine kada i Rustem (1730.) također traži da se pokupi yemeklik za hercegovačkoga valiju, ali za 1140., odnosno 1727. godinu, kada je namjesnik Hercegovine bio Ahmedpaša. ${ }^{18}$ Iako su navedeni nameti do 18 . stoljeća već postali "uobičaje-

14 Sidžil blagajskog kadije 1728. - 1732., str. 57. U prevedenom dokumentu stoji da se radi o fermanu sultana Ahmeda III. Međutim, početkom listopada 1730. došlo je do smjene na osmanskom prijestolju, kada umjesto Ahmeda III. na prijestolje dolazi njegov nećak, Mahmud I. Ovdje je vjerojatno omaškom krivo upisan datum ili ime sultana.

15 Sidžil blagajskog kadije 1728. - 1732., str. 58.

16 Yemeklik je jedan od nameta koji je nastao kao posljedica zlouporabe vlasti. On se još 1624. godine smatrao novotarijom, a označavao je doprinos za hranu dužnosniku koji ga ubire. Yemeklik također predstavlja sinonim za peşkeş, što znači poklon. Avdo Sućeska, "Promjene u sistemu izvanrednog oporezivanja u Turskoj u XVII vijeku i pojava nameta tekâlîf-i şâkka", u: POF, 10-11, Sarajevo, 1961., str. 94 (tekst i bilj. 92). Više o izvanrednim porezima vidi u navedenom radu. Isto, str. 75-112.

17 Saliyana se javlja krajem 17. stoljeća. Predstavlja izvanredni namet u korist pokrajinske vlasti. Isto, str. 95-96 (tekst i bilj. 102).

18 Sidžil blagajskog kadije 1728. - 1732., str. 19-21, 27-28, 55. Ahmed-paša i Rustem-paša u više su navrata tijekom 1729. i 1730. godine od stanovnika tražili 
ni" nameti na koje su namjesnici imali pravo, učestalost traženja tih i drugih nameta, kao i iznosi koje je stanovništvo moralo izdvajati, bio je prevelik pritisak pa stoga nije ni čudo što se raja žali i tuži sultanu. Tu treba pridodati i poreze imdad-i seferiye (ratna pomoć) i imdad-i hazariya (mirnodopska pomoć), ${ }^{19}$ koji su pokrivali troškove namjesnika u ratnim i mirnodopskim vremenima, a koji su od 18 . stoljeća također postali uobičajena obveza, te niz drugih "starih" poreza i nameta.

Iako je bilo naređeno da se vrati sve što je protuzakonito i silom bilo oduzeto u vrijeme valije Ahmed-paše, ${ }^{20}$ ne znamo je li to uistinu i učinjeno. U bujuruldijama se jasno ističe kako su Ahmed-paša i Rustem-paša činili nasilja tražeći protuzakonito od raje i kapetana novac, ali nigdje u dokumentima nema naznake da su otac i sin na bilo koji način kažnjeni. Štoviše, Rustem-paša bujuruldijom od 15. rebia I 1144. (rujan 1731.) obavještava blagajskoga kadiju kako mu je "carskom naredbom od 27. safera 1144. (kolovoz 1731.) predan hercegovački sandžak kao arpaluk [dodatni prihod]". ${ }^{21}$ Naredba je došla

novac na ime saliyane te za izgradnju tvrđava. Isto, str. 28-31, 34-35, 39-43, 63. O kojim se iznosima radilo najbolje pokazuje popis sela blagajskoga kadiluka koji su na ime saliyane i izgradnju sarajevske tvrđave u siječnju 1731. godine morali dati ukupno 229.45 akči. Isto, str. 34-35.

19 Imdad-i hazariya (skraćeno hazariya) naziv je za porez koji se u bosanskohercegovačkim i susjednim znanstvenim krugovima pogrešno naziva taksit. $\mathrm{Na}$ to je u svome istraživanju o terminu taksit ukazao Fahd Kasumović, koji argumentima potkrepljuje tvrdnju kako je taksit samo jedna rata mirnodopskog poreza hazariya koji se prikupljao za namjesnike, a ne cjelovit porez ili oznaka za više poreza kako se to ponekad navodi. Više o tome u: FAHD Kasumović, "O terminu taksit: nesklad izvora i literature", u: Prilozi, 38, Sarajevo, 2009., str. 61-79.

20 U bujuruldiji kajmekama Bosne Huseina, od 9. džumada II 1143. (prosinac 1730.) upućenoj kadijama Mostara i Blagaja, mostarskom kapetanu, agama nefera, ajanima vilajeta i poslovnim ljudima naređuje se "da se vlasnicima povrati sve što je od njih silom i protuzakonito oduzeto za vrijeme uprave prijašnjeg valije" (misli se na Ahmed-pašu, op. a.). Sidžil blagajskog kadije 1728. - 1732., str. 51.

21 Sidžil blagajskog kadije 1728. - 1732., str. 75. To nije bilo prvi put da je Rustempaša dobio Hercegovinu kao arpaluk. Iz jednog fermana sultana Ahmeda III. vidimo da je Rustem-paši i 17. džumada II 1142. (siječanj 1730.) sandžak Hercegovina dodijeljen kao arpaluk i istovremeno potvrđeno mjesto mutesarifa (istoznačnica za sandžak-bega). Sidžil blagajskog kadije 1728. - 1732., str. 16. Zanimljivo je da je samo nekoliko dana prije no što je Rustem-paša ponovo dobio Hercegovinu kao arpaluk, izdat ferman Muhamedu Selimpašiću ko- 
prije nego je izdan ferman kojim sultan naređuje uhićenje ćehaja, ali prema podatcima koje donosi Bašagić, Rustem-paša je sve do 1735. godine bio hercegovački namjesnik. ${ }^{22}$

Porezna opterećenja jednako su pogađala i muslimane, zbog čega je muslimanska raja nastojala izbjeći plaćanje poreza i nameta stupanjem $\mathrm{u}$ različite vojne službe. ${ }^{23} \mathrm{Zbog}$ sve većih poreznih pritisaka i izrabljivanja predstavnika upravne vlasti, muslimanska raja nije mirovala. U nemirima koji su uslijedili sve više pokazuju svoje nezadovoljstvo, što će se sredinom 18. stoljeća prometnuti u višegodišnji ustanak u kojemu će glavnu ulogu imati upravo muslimansko stanovništvo. ${ }^{24}$ Mehmed-paša Kukavica 1752. godine zavodi red surovo se obračunavajući s ustanicima. Zahvaljujući smirivanju pobune krajem iste godine postao je bosanskim namjesnikom, ali će svojim ponašanjem izazvati nove nerede. Njegovo nasilje izazvalo je 1760.

jega se također postavlja za hercegovačkog mutesarifa i sandžak Hercegovina dodjeljuje mu se kao arpaluk. Ferman je izdan 21. safera 1144., samo šest dana prije nego je izdan ferman Rustem-paši. Očito je u međuvremenu došlo do promjene u korist Rustem-paše, vjerojatno na nečiji zagovor kod sultana. Samo tako se može objasniti ova zbrka i nered koji je nastao oko dodjeljivanja hercegovačkog sandžaka. Selimpašić po svoj prilici nije još bio obaviješten o toj promjeni kada je 16. rebia II 1144. (listopad 1731.) poslao obavijest hercegovačkim kadijama o svom imenovanju. Sidžil mostarskog kadije 1730. - 1733., list $5 / b$.

22 SAFVET-Beg BAŠAgić-RedžEPAšić, Kratka uputa u prošlost Bosne i Hercegovine. Od 1463. do 1850, vlastita naklada, Sarajevo, 1900., str. 184.

23 U predstavci blagajskoga kadije Saliha upućenoj bosanskom valiji 1734. godine navodi se kako su "Žuljevići iz Kamene, Milišići iz Kokorine, Dedići iz Kružnja, Memija Ivanišević iz nahije Dubrave i drugi," od kojih većina pripada u skupinu čifčija, odnosno radnika na feudalnim posjedima, stupili u službe alajbega, mustahfiza ili postali članovi tvrđavskih posada. Spomenuti izbjegavaju plaćati dio poreza, tako da sav teret poreznih obveza pada na leđa siromašne raje koja zbog toga bježi iz blagajskoga kadiluka. Kadija moli valiju da preko svoga povjerenika naplati od spomenutih ono što duguju. Sidžil blagajskog kadije 1697. - 1793., list 5/b.

24 O bunama i ustanku sredinom 18. stoljeća više u: M. HaDžıjahić, "Bune i ustanak u Bosni...", str. 99-137. O seljačkim bunama u Bosanskom ejaletu te njihovim uzrocima više je studija napisao Avdo Sućeska. Izdvajamo neke od naslova: Avdo SućEska, "Bune seljaka Muslimana u Bosni u XVII i XVIII stoljeću", u: Zbornik radova, I., Istorijski institut, Beograd, 1976., str. 69-100. IstI, "Seljačke bune u Bosni u XVII i XVIII stoljeću", u: Godišnjak Društva istoričara, XVII., Sarajevo, 1969., str. 163-207; IsTI, "O socijalnim i političkim pokretima bosanskih Muslimana u XVIII stoljeću", u: Pregled, god. LXXIV. (5), Sarajevo, 1984., str. 523-536. 
godine bunu u Mostaru, zbog čega je krajem svibnja iste godine krenuo na Mostar. Mostarci su ga dočekali i ubili nekoliko ljudi iz njegove pratnje. Nakon toga događaja i pritužbi Mostaraca Porti o njegovu nasilnom ponašanju prema muslimanima, Kukavica je smijenjen $s$ položaja bosanskoga namjesnika i ubrzo nakon toga smaknut. ${ }^{25}$

Samovolja kadija, naiba i drugih predstavnika vlasti koji naplaćuju skuplje takse pri dodjeli timara i zeameta, te se služe lažima i bave radnjama koje su u suprotnosti sa zakonom i šerijatom postaje uobičajena pojava. ${ }^{26} \mathrm{O}$ raspoloženju stanovništva u Hercegovini 18. stoljeća govori bujuruldija bosanskoga valije od 23. muharema 1182. (lipanj 1768.) naslovljena kapetanu stolačke tvrđave i dizdaru, kojom ih obavještava "da su neke age i stanovnici, muslimani i raja, otkazali poslušnost i neće da pomognu izgradnju tvrđava u Bosni". ${ }^{27} \mathrm{~S}$ obzirom na ratove koje Osmansko Carstvo vodi tijekom 18. stoljeća protiv Austrije, Rusije, Perzije, Crne Gore, a u kojima aktivno sudjeluje i muslimansko stanovništvo, razumljivo je njihovo nezadovoljstvo i

25 Mula Mustafa ŠEvki Bašeskija, Ljetopis (1746 - 1804), prev. Mehmed Mujezinović, Veselin Masleša, Sarajevo, ${ }^{2}$ 1987., str. 46; Usp. M. Hadžıja hić, "Bune i ustanak u Bosni...", str. 121-122. Mehmed-paša Kukavica u dva je navrata bio bosanskim namjesnikom (1752. - 1756. i 1757. - 1760.). O njegovu životu i djelu više u: AlıjA Bejtić, "Bosanski namjesnik Mehmed paša Kukavica i njegove zadužbine u Bosni (1752 - 1756 i 1757 - 1760)", u: POF, 6-7, Sarajevo, 1956. - 1957., str. 77-114.

26 Kako je zbog zlouporaba i središnjica morala intervenirati, s Porte 1. zulhidžeta 1179. (svibanj 1766.) upozoravaju da svi svoje dužnosti trebaju vršiti u skladu sa šerijatom i zakonom ili će biti kažnjeni. Sidžil mostarskog kadije, fragmenti iz 1179 - 1182. h. g./1765 - 1769. g. (regesta), obradio Hivzija Hasandedić, IC štamparija Mostar, Mostar, 2014., str. 51.

27 Sidžil blagajskog suda, fragmenti iz 1141 - 1203 (1729. - 1789.), list 47/b. Stanovništvo je zbog ratnih okolnosti tijekom 18. stoljeća redovito moralo raditi na popravci ili izgradnji tvrđava na prostoru cijeloga ejaleta. Kadiluci su bili dužni osigurati određen broj konja, zidara i različitoga građevinskog materijala, a zbog radova radnici su po nekoliko mjeseci izbivali iz svojih domova. Majstorima i onima koji su prevozili građevinski materijal propisivana je skromna novčana naknada, no zbog učestalosti traženja i dužine trajanja radova ta je obveza bila prevelik teret za stanovništvo. Samo u razdoblju od 1765. do 1769. više od deset puta različitim je kadilucima naređivano slanje konja s robom i zidara koji su trebali raditi na opravci različitih tvrđava. Sidžil mostarskog kadije, fragmenti iz 1179 - 1182. h. g./1765 - 1769. g., str. 49, 53, 80, 81, 87-88, 116; Sidžil nevesinjskog kadije 1767. - 1775. godine (regesta), obradio Hivzija Hasandedić, Arhiv HNK/Ž Mostar, 2009., str. 39; Sidžil blagajskog kadije 1702. - 1798., list 21/a; Sidžil blagajskog suda, fragmenti iz 1141 - 1203 (1729. - 1789.), list. 17/a, 18/b, 78/b. 
otpor. Osmanska je država bila uvučena u sukobe koji su zahtijevali ne samo vojni, nego i civilni angažman. Upravo je stanovništvu stavljena obveza da tijekom ratnih pohoda opskrbi vojsku potrebnim namirnicama ili joj osigura konačište, što je za podanike bio dodatni pritisak i njihov je položaj činilo još težim. ${ }^{28}$

Do kraja stoljeća situacija se ne će značajnije promijeniti. Osmansko Carstvo suočava se s novim prijetnjama i sukobima, a Bosanski ejalet i njegovo stanovništvo prepušteno je lokalnim upraviteljima. $\mathrm{Ni}$ u ratnim godinama nisu mogli računati na značajniju pomoć $s$ Porte, tako da je muslimansko stanovništvo bilo prisiljeno svojim snagama braniti se od vanjskih napada. Kulminacija tih zbivanja bio je i austrijsko-osmanski rat (1788. - 1791.), poznat i kao Dubički rat, u kojemu su kod Dubice bosanski muslimani pružili jak otpor. Sklapanjem Svištovskoga mira 1791., nemiri su na prostoru Bosanskoga ejaleta za jedno izvjesno vrijeme prestali, ali potpuna sigurnost i mir bili su samo misaone imenice. Za cijelo to vrijeme hajdučke družine vrše prepade i pljačke, ne birajući svoje žrtve.

\section{Hajdučko djelovanje i pokušaji vlasti da zaštite stanovništvo}

Potpisivanje mira u Srijemskim Karlovcima 1699. godine nije označilo i prestanak hajdučkoga djelovanja, niti je na prostoru Bosanskoga ejaleta pa tako ni Hercegovine donijelo prijeko potreban mir. Hajduci i početkom 18. stoljeća nastavljaju sa svojim pljačkaškim akcijama, zbog čega su osmanske vlasti osiguravale putne pravce koji su bili najviše na udaru. Bosanski muhafiz ${ }^{29}$ Halil-paša u bujuruldiji poslanoj 18. muharema 1114. (lipanj 1702.) kadijama Mostara i Blagaja, mostarskom kapetanu, blagajskom dizdaru te ostalim agama nefera naređuje da se svi moraju angažirati u zaštiti prolaza i klanaca na potezu od Mostara prema Sarajevu, kao i od Mostara prema Nevesinju, zatim od kule Lipeta do Nevesinja te "na putevima od strane

28 Bezbroj je primjera u kojima se na muslimansko i kršćansko stanovništvo stavlja obveza opskrbe ili konačenja vojske tijekom ratnih pohoda, ali i kulučenje. Tijekom sukoba s Crnom Gorom (1766. - 1769.) više je puta propisivano stanovnicima mostarskoga i drugih hercegovačkih kadiluka koliko hrane moraju osigurati pašinoj vojsci, a neke je naredbe zbog odugovlačenja odgovornih trebalo i više puta ponavljati. Sidžil mostarskog kadije, fragmenti iz 1179 - 1182. h. g./1765 - 1769. g., str. 43-47, 54-55, 120-126.

29 Muhafiz ima više značenja. Najčešće je to zapovjednik posade u tvrđavi, ali od 18. stoljeća termin muhafiza koristi se i za pokrajinske namjesnike. 
Počitelja, Imotskog, Duvna i na svim stranama desno i lijevo". Prolaze treba osiguravati do Mitrovdana, ${ }^{30}$ a dužni su osigurati i dovoljan broj vojnika te neprekidno pratiti kretanje hajduka kako bi ih pohvatali. Muhafiz upozorava odgovorne da ukoliko hajduci i "dalje budu dočekivali svijet i pljačkali ga bićete pozvani svi na odgovornost i kažnjeni". ${ }^{31}$ Vjerojatno je ova naredba posljedica događaja koji su se malo prije toga dogodili u Prologu kod Ljubuškog. O tim događanjima saznajemo iz pisma bosanskoga valije Halil-paše koje je uputio mletačkom providuru Alvisu Mocenigu 1. lipnja 1702., a u kojem stoji kako Sinobadov sestrić i Vid Petrović iz Kosova (misli se na dalmatinsko Kosovo, op. a.) sa 60 hajduka u Prologu pljačkaju putnike te napadaju i ubijaju nefere. Također navodi kako su napali i porobili jedno selo u blizini Atlagića kuća. ${ }^{32}$ Iz pisma je vidljivo da spomenuta hajdučka družina nije prijetila Prologu jedan dan, nego su tu boravili jedno izvjesno vrijeme. Kako bi ponovo uspostavili kontrolu i sigurnost, odgovorni su morali reagirati, zbog čega je i uslijedila naredba Halil-paše o osiguravanju putova.

U izvorima nailazimo na jednu prazninu od 20-ak godina, pa je nepoznato koliko je ta mjera bila učinkovita i u kojoj je mjeri utjecala na smanjenje hajdučkih pohoda, ali ih zasigurno nije spriječila. Pljačke i prepadi na putovima bili su dio svakodnevice i svi koji su putovali s bilo kakvom robom ili dragocjenostima mogli su očekivati takvo što. Jedna od žrtava bio je i Deli-Osman, kojega su odmetnici napali na putu za Nevesinje i oteli mu konja s robom. Ne znamo kada se to točno dogodilo, ali hercegovački valija Rustem-paša već 3. safera 1141. (rujan 1728.) šalje bujuruldiju kojom naređuje blagajskom naibu da slučaj ispita i pronađe odgovorne. Kako se napad dogodio dva sata udaljenosti od Blagaja, naređeno je da se krivce potraži u

30 Mitrovdan je praznik posvećen sv. Dimitriju, svecu kojega 26. listopada slavi Istočna i Zapadna Crkva. U Katoličkoj se Crkvi često obilježava uz ime Zvonimir (hrvatski kralj Zvonimir nosio je njegovo ime, Dmitar). Nakon što su mu relikvije iz Srijemske Mitrovice, gdje je pogubljen, prenesene u Solun, njegovo se štovanje proširilo na Istok. Više o svetom Dimitriju u: Leksikon ikonografije, liturgike i simbolike zapadnog kršćanstva, AnĐELKo BADURInA (ur.), Sveučilišna naklada Liber - Kršćanska sadašnjost - Institut za povijest umjetnosti, Zagreb, 1979., str. 203. Mitrovdan je također poznat kao hajdučki rastanak, dan kada se hajdučke družine raspuštaju i do proljeća prestaju s pljačkaškim akcijama.

31 Sidžil blagajskog kadije 1698. - 1779., list 19/a.

32 BošKo DesnicA, Istorija kotarskih uskoka (1684 - 1749), sv. II., Beograd, 1951., str. 375. 
selima najbliže mjestu događaja: Kokorini, Kamenoj i Vranjevićima. U svezi Deli-Osmana, Hasan čelebija Velagić i Husein Čusto tužili su stanovnike Vranjevića da je spomenutom Deli-Osmanu nestao konj kada je u svojstvu mubašira (državnog izaslanika) došao u njihovo selo, kao i da su mu odbili dati hranu. ${ }^{33}$ Tužba nije datirana i ne donosi više podataka o samom slučaju, ali se vjerojatno radi o istom događaju. Bilo bi zaista nevjerojatno da istu osobu dva puta napadnu gotovo na istom mjestu. Sigurno da je Deli-Osman kao valijin čovjek od povjerenja bio meta jer su mubaširi, između ostaloga, imali zadatak prikupljati novac za izgradnju tvrđava, zbog čega su i bili u opasnosti od pljačkanja, ali nakon jednoga napada sigurno bi prilikom novoga putovanja poduzeo određene mjere sigurnosti.

Vjerojatno su ovi i slični događaji bili povod da već iste godine u prosincu (24. džumada) novi hercegovački valija Ahmed-paša kadijama Mostara, Blagaja, Nevesinja, Stoca i Cernice, kapetanima tvrđava od Mostara do Nikšića, te drugim vojnim zapovjednicima i uglednicima ponovi naredbu kojom im naređuje da na području navedenih kadiluka "pohvataju sve odmetnike" i zatvore ih u tvrđavama. ${ }^{34} \mathrm{Ne}$ znamo koliko su poduzete mjere bile učinkovite, ali iz daljnjih zapisa vidimo da hajduci postaju sve bezobzirniji i smioniji u svojim akcijama. Išli su tako daleko da su stanovništvu nametali terete, zbog čega je ono tražilo spasa u bježanju iz svojih domova i preseljenju u druge krajeve. O tome svjedoči naredba hercegovačkog kajmekama Ahmeda od 13. safera 1144. (kolovoz 1731.) kojom od kadija i kapetana tvrđava u Hercegovačkom sandžaku, te vojvoda, imama i drugih uglednih osoba traži da pohvataju sve hajduke koji po kasabama i selima "prave razne smutnje, opterećuju siromašnu raju sa traženjem protuzakonitih nameta koje oni ne mogu snositi" čime prisiljavaju raju da "napuštaju svoje domove i bježe". ${ }^{55}$ Iako nisu navedena imena hajduka, ne treba isključiti mogućnost da se ovdje radi o muslimanskim hajducima, odnosno gradskoj mafiji koja je djelovala u gradskim i prigradskim naseljima, a koju spominje i Hrabak. Evo što on o tome bilježi: "Gradska mafija je često povezana sa prigradskim akterima, pa se i realizacija varoških organizatora ostvaruje van gradskog naselja". ${ }^{36}$ Prema tome, ovdje se čak moglo raditi i o zajedničkoj

33 Sidžil blagajskog kadije 1728. - 1732., str. 25.

34 Isto, str. 32.

35 Isto, str. 65.

36 B. Hrabaк, "Hajdučija u Bosni i Hercegovini...", str. 286. 
suradnji kršćanskih i muslimanskih hajduka, jer ni takvi nastupi nisu bili isključeni. $U$ dokumentu nije precizirano o kakvim se nametima radilo, ali uz već postojeće koje je stanovništvo bilo dužno snositi, hajdučka potraživanja dodatno su pogoršavala položaj seljaka. Tome treba pridodati i bezobzirnost lokalnih moćnika koji su nezakonito potraživali novac, o čemu je već bilo govora. Osim toga, od 1717./1718. i 1719. godine Porta je donijela dvije porezne odredbe kojima se namjesnicima u pokrajinama odobrava ratna i mirnodopska pomoć za njihovo izdržavanje, a koje je opet moralo davati stanovništvo. ${ }^{37}$ Osim tih obveza stanovništvo je također plaćalo mubašira, troškove njegova konačenja, troškove administracije, a prilikom putovanja valije stanovništvo je moralo popraviti sve putove, mostove i klance. ${ }^{38}$ Uza sve navedeno, kao i druge ranije uvedene obveze koje je raja bila dužna izvršavati, nije ni čudo što spas traži u bježanju. Hajduci su i ranije stanovništvu nametali terete, tako da to nije bila novìna koja se pojavila u 18. stoljeću. Tijekom Kandijskoga rata zabilježeno je da su hajduci 1658. godine svim selima do Gacka nametnuli danak koji su prikupljali u skupinama od po 10 do 12 ljudi. Oni koji bi se tome odupirali, bili su kažnjavani. ${ }^{39}$ Očito je takva praksa nastavljena i u 18. stoljeću.

Naredba kajmekama Ahmeda iz 1731. godine nije se u potpunosti sprovela, jer već sljedeće godine, 13. zulhidžeta 1144. (lipanj 1732.), bosanski valija Ibrahim-paša šalje bujuruldiju kojom kadijama Mostara i Stoca, kapetanima i agama nefera naređuje da "bezuvjetno pronađu sve odmetnike koji pljačkaju svijet i čine mu razna nasilja" te da ih zatvore i kazne. ${ }^{40} \mathrm{O}$ kakvim se sve nasiljima radilo najbo-

37 F. Kasumović, "O terminu taksit: nesklad izvora i literature", str. 66. U sidžilima se na više mjesta nalaze popisi sela i iznosi koje je svako pojedino mjesto moralo dati na ime ratne pomoći ili seferiye i mirnodopske pomoći, odnosno hazariye, koja je prikupljana u dvije rate. Događalo se da lokalni moćnici zlorabeći svoj položaj više puta traže spomenute poreze. Prema jednom dokumentu iz 1766. godine raja iz mostarskoga kadiluka uputila je arzulah, odnosno predstavku bosanskom valiji kojom se žale na naiba koji od njih potražuje zimski taksit, iako su ga oni ranije prikupili i predali valijinoj blagajni. Žale se da će se morati raseliti, ukoliko se naibu ne zabrani nezakonito potraživanje. Sidžil mostarskog kadije, fragmenti iz 1179 - 1182. h. g./1765 - 1769. g., str. 34.

38 M. Hadžijahić, "Bune i ustanak u Bosni..." str. 101.

39 Vojislav Korać, Trebinje II: period od dolaska Turaka do 1878. godine, Zavičajni muzej, Trebinje, 1971., str. 104.

40 Sidžili mostarskog kadije, fragmenti iz 1044 - 1207. h. god./1635 - 1793. godine (regesta), obradio Hivzija Hasandedić, Arhiv HNK/Ž, Mostar, 2011., str. 35. 
lje pokazuje slučaj iz 1733. godine u jednoj kući na Radobolji, oko sat vremena hoda od Mostara (s obzirom na udaljenost od Mostara, vjerojatno se radi o Vrelu Radobolje u Ilićima, op. a.). Zabilježeno je da su 16. dan ramazana 1145. (veljača 1733.) razbojnici Rado, Vukosav Vukčić iz Prhova, Nikola Vulić iz Crnča i Milosav iz Raštana opljačkali kuću Džafer-bega i Ali-bega Ziraizade i pritom ubili sedam članova kućanstva, a troje ranili. Razbojnici su uhvaćeni i zatvoreni, a bosanski muhafiz Abdulah-paša naređuje odgovornima u mostarskom kadiluku da "dobro ispitaju ima li hajduka, da ih sve pohvataju i dovedu i predaju Bosanskom divanu radi izricanja zaslužene kazne".41 Nejasno je jesu li navedeni razbojnici bili članovi hajdučke družine, ali iz novih naredbi koje su uslijedile 6. i 14. ševala 1145. (ožujka 1733.), a u kojima se naređuje hvatanje odmetnika zbog zločina u Džafer-begovoj kući, daje se naslutiti da spomenuti razbojnici nisu djelovali samostalno i da su se neki od njihovih drugova još nalazili na slobodi. ${ }^{42}$ Osim toga, čini se da su bili u dosluhu i s vojnim predstavnicima. Nije bilo neuobičajeno da i vojni predstavnici potaknuti nepravdom ili osobnim interesima šuruju s razbojnicima. To pokazuje slučaj glavnoga age mostarske tvrđave Huseina i Ahmeda Lakišića, koje se optužuje za suradnju s hajducima. U ožuj$\mathrm{ku}$ iste godine (1733.) bosanski valija Abdulah-paša u dva navrata traži da se spomenuti dvojac privede na Bosanski divan zbog suradnje s odmetnicima. U prvoj bujuruldiji od 14. ševala 1145. upućenoj mostarskom kadiji, ajanu Hasanagi i drugim odličnicima, naređuje im da "bezuvjetno pronađu osam hajduka i Ahmedagu Lakišića i Huseinagu, glavnog agu mostarske tvrđave" te ih povezane dovedu na Bosanski divan. Nekoliko hajduka se također navode poimence. To su: Ivan Bojlo iz Mokrog, Matija Knezović iz Medvidovića, još jedan Ivan (prezime nije navedeno) i četvorica iz sela Međugorja, Planinice i Dobrog Sela, koji su okrivljeni zbog nasilja i pljačke koje čine stanovnicima sela nahija Blato i Brotnjo. Kako naređenje nije dalo očekivane rezultate, bosanski je valija četiri dana kasnije na iste adrese uputio novu bujuruldiju kojom im još jednom naređuje da spomenutu dvojicu pronađu i predaju Bosanskom divanu, jer "pomažu razbojnike i prave razne smutnje". ${ }^{43} \mathrm{Ne}$ znamo o kakvim se "smutnjama" radilo, niti kako je ova priča završila, jer se u sudskim zapisima više ne može pratiti. Teško je ustvrditi je li ova razbojnička

41 Isto, str. 37.

42 Isto, str. 37-38.

43 Isto, str. 38. 
družina bila dio skupine koja je napala kuću Džafer-bega, ali ovakve akcije u neposrednoj blizini Mostara, sjedištu kapetanije, nisu se mogle događati bez suradnje ili barem znanja onih koji su takva djela trebali sprječavati. Kako u sidžilima više ne nailazimo na ovaj slučaj, možemo samo pretpostaviti da su okrivljeni primjereno kažnjeni.

Feudalni pritisak, izrabljivanja i nepravde pogađali su jednako i kršćansko i muslimansko stanovništvo, što je dovodilo do zajedničkih pothvata i udruživanja koja su znala potrajati i nekoliko godina. Još krajem 17. stoljeća (1698.) odmetnici Stojan Ćosić iz Mokrog i Jakov Gerin iz Plužine udružili su se s Koski Mehmedom i Šabanom Havadžom iz kasabe Mostar i sprječavali naplatu džizije (glavarine). U dva su navrata početkom 18. stoljeća zajedno s "ruljom" napali mehkemu (sudnicu), a odbili su sudjelovati i u popravci mostarske tvrđave. ${ }^{44}$ Ovo udruživanje i zajednički kršćansko-muslimanski pothvati bili su prije svega posljedica ratnih i poratnih okolnosti, ali iz naprijed izloženoga vidimo da ni kasnijih godina situacija nije bila bolja. Uza sva naređenja i nastojanja u suzbijanju razbojstava, ona se nisu mogla spriječiti. Intervencije Porte bile su u najmanju ruku mlake, a u prilog im nije išla ni sve izraženija feudalna anarhija i samovolja koja će sredinom stoljeća dovesti do višegodišnjih nemira koji ne će zaobići ni Hercegovinu.

Smjena bosanskoga valije Kukavice 1760. godine nije značajnije utjecala na sigurnost i smanjenje hajdučkih akcija. Osmanske su vlasti pokušavale zaštititi stanovništvo od nasilja, a odgovorne kazniti. Međutim, ti su pokušaji uglavnom ostajali bezuspješni, a ni izravne prijetnje s Porte upućene odgovornima nisu imale većega učinka. U bujuruldiji od 4. ševala 1176. (travanj 1763.), upućenoj odgovornim osobama u kadilucima (nije navedeno o kojim se točno kadilucima radi) jasno se ističe da je prva i osnovna dužnost ajana, zabiti i drugih službenika zaštita stanovništva i njihove imovine od napada odmetnika i hajduka. Od spomenutih se traži da u sporazumu sa stanovništvom pohvataju razbojnike i vezane ih pošalju na Bosanski divan. Također se napominje da ukoliko odmetnici ubuduće nastave s pljačkanjem i napadima na stanovništvo "biće kažnjeni zabiti, ajani i službenici i iz njihovih imetaka će se sva šteta naplatiti". ${ }^{45} \mathrm{Ne}$ znamo jesu li odgovorni za sigurnost i red kažnjeni, ali znamo da su hajduci i dalje nastavili po starom. To pokazuje bujuruldija bosanskoga

44 M. Hadžijahić, "Bune i ustanak u Bosni...", str. 103.

45 Sidžil blagajskog kadije 1698. - 1779., list 33/a. 
valije od 25. zulkadeta 1177. (svibanj 1764.) kojom hercegovačkim kadijama i kapetanima od Mostara do Cernice, agama, zabitima, te ajanima vilajeta i službenicima naređuje da se s potrebnim brojem pandura osiguraju prolazi i opasna mjesta, kako bi stanovnike i putnike zaštitili od štete i nasilja koju im čine hajduci i odmetnici. ${ }^{46}$ Tijekom sljedećih nekoliko godina upućeno je više naredbi i upozorenja odgovornima da se stanovništvo zaštiti od nasilja, hajduke pohvata i putovi osiguraju. ${ }^{47}$ Često ponavljanje namjesnicima i vojvodama da im je osnovna uloga štititi raju i druge stanovnike od nasilja najbolji je pokazatelj koliko su ta naređenja i upute bili (ne)djelotvorni. Nisu pomagale ni intervencije s Porte, odakle su krajem muharema 1182. (lipanj 1768.) uputili ferman svim kadijama i zapovjednicima Rumelije u kojemu se po tko zna koji put naglašava da svim lojalnim podanicima treba osigurati mir, a nasilnike spriječiti u njihovu djelovanju i "odmah kažnjavati". ${ }^{8}$

Unatoč poduzetim mjerama, sidžili bilježe nova hajdučka zlodjela. U bujuruldiji od 28. rebia II 1183. (kolovoz 1769.) zabilježeno je da su hajduci Miloš Čabak i njegov brat Mihajlo iz Lukovice, ${ }^{49}$ kod Konjica ubili čohodara (vojni ili civilni službenik) Mehmeda. Bosanski valija Mehmed-paša naređuje nevesinjskom kadiji, ajanu i službenicima da uhvate spomenute hajduke i dovedu na Divan zbog suđenja. Znakovito je da se ubojstvo dogodilo samo nekoliko mjeseci nakon

46 Sidžil blagajskog suda, fragmenti iz 1173 - 1250 (1760. - 1835.), list 77/a.

$47 \mathrm{O}$ nastojanjima suzbijanja hajdučije i zaštite stanovništva svjedoči i jedna bujurldija bosanskoga kajmekama Sejid Mehmeda iz 1767. u kojoj kadijama Mostara, Blagaja, Stoca, Ljubinja, ostatka Novog, Cernice, Foče, kapetanima, zabitima, ajanima vilajeta i službenicima naređuje da osiguraju klance i prolaze s potrebnim brojem muhafiza, jer će se "hajduci početkom proljeća odmetnuti u brda i početi dočekivati i pljačkati putnike". Sidžil mostarskog kadije, fragmenti iz 1179 - 1182. h. g./1765 - 1769. g., str. 80. Slične naredbe izdavane su i kasnijih godina. Sidžil mostarskog kadije, fragmenti iz 1179 - 1182. h. g./1765 - 1769. g., str. 50, 125; Sidžil nevesinjskog kadije 1767. - 1775., str. 27-28; Sidžil blagajskog suda, fragmenti iz 1183 - 1201 (1769. - 1787.), list 20/a; Sidžil blagajskog suda, fragmenti iz 1141 - 1203 (1729. - 1789.), list. 25/a, 78/a; Sidžil blagajskog suda, fragmenti iz 1183 - 1201. (1769. - 1787.), list, 20/a; Sidžil blagajskoga suda, fragmenti iz 1173 - 1250 (1760. - 1835.), list 70/b, 75/b, 76/b; Sidžil blagajskog suda, fragmenti iz 1113 - 1212 (1702 - 1798), list 34/a.

48 Sidžil mostarskog kadije, fragmenti iz 1179 - 1182. h. g./1765 - 1769. g., str. 127-128.

49 U Hercegovini postoji mjesto Lukovice u općini Gacko, dok u Crnoj Gori postoji visoravan Lukavica, gdje su boravili katunari. Ovdje se vjerojatno radi o crnogorskoj Lukavici. 
što je valija bujuruldijom od 27. zulhidžeta 1182. (svibanj 1769.) naredio kadijama Foče, Cernice, Nevesinja, Ljubinja, Mostara, Blagaja, muteselimu Hercegovačkog sandžaka, kapetanima, agama i drugim službenicima da "žive ili mrtve" pohvataju sve hajduke i odmetnike te ih po šerijatu kazne..$^{50} \mathrm{U}$ dokumentima se nigdje ne spominje jesu li okrivljeni hajduci uhvaćeni i privedeni na suđenje. Pretpostavimo li da jesu, moguće je da su otkrili pomagače ili barem nagovijestili da su ih imali, a ne treba isključiti ni mogućnost da je vlasti netko drugi o tome obavijestio. Na to upućuje bujuruldija ćehaje bosanskog valije Sulejmana od 1. redžepa 1184. (studeni 1770.), u kojoj stoji kako su obaviješteni da je čohodara ubio jedan Crnogorac, a ubojicu je netko od raje iz Nevesinja, gdje je bio došao, doveo do Konjica. Stoga se nevesinjskom kadiji, ajanu i službenicima naređuje da pohvataju sve hajduke i njihove jatake te ih ispitaju. ${ }^{51}$ Iste godine kada je ubijen $\check{c} o-^{-}$ hodar Mehmed, na dva sata udaljenosti od Konjica (vjerojatno negdje kod Jablanice, op. a.) napadnut je i opljačkan neimenovani mubašir kome su napadači oteli 2000 groša. Isprava ne donosi nikakvih drugih podataka o napadačima, osim da ih se privede "žive ili mrtve". ${ }^{2}$

Hajduci nisu napadali samo bogate predstavnike vlasti. Njihovim žrtvama jednako su bili i oni najsiromašniji, na što upućuje zapis iz 1763. godine kada se uglednicima i vojnim službenicima naređuje da zaštite "sve stanovnike, nemoćne, siromahe, raju i putnike namjernike", ali isto tako da zaštite i osiguraju "njihova imanja i usjeve od odmetnika i hajduka". ${ }^{33}$ Ovo nije jedini takav primjer koji pokazuje da hajduci ne biraju žrtve. Iz bujuruldije neimenovanog pošiljatelja iz 1780. godine upućene kadijama Nevesinja, Cernice, Blagaja, Stoca, ostatka Novog, Ljubinja i Konjica, između ostaloga stoji da na proljeće, kada hajduci i odmetnici počnu raditi zlodjela i "kada počnu napa-

50 Sidžil nevesinjskog kadije 1767. - 1775., str. 45, 52. Prve vijesti o ubojstvu čohodara Mehmeda su od 12. rebia II 1183. (kolovoz 1769.), kada bosanski valija Silahdar Mehmed-paša naređuje kadijama Blagaja, Nevesinja, ajanu, zabiti i službenicima da pohvataju one koji su ubili čohodara Mehmeda kod Konjica. U ovoj se ispravi ne navode imena ubojica. Sidžil blagajskog suda, fragmenti iz 1141 - 1203 (1729. - 1789.), list 35/b.

51 Sidžil nevesinjskog kadije 1767. - 1775., str. 37.

52 Sidžil blagajskog suda, fragmenti iz 1183 - 1201 (1769. - 1787.), list 2/a. Nepotpunu ispravu o istom događaju nalazimo i u sidžilu nevesinjskoga kadije, u kojoj se osim opljačkanoga iznosa i mjesta na kojem se prepad dogodio navodi i ime opljačkanog mubašira, Mehmedaga. Sidžil nevesinjskog kadije 1767. 1775., str. 11.

53 Sidžil blagajskog kadije 1698. - 1779., list 33/a. 
dati siromašnu raju i putnike i počnu im otimati imetak i ubijati ih", obavijeste Bosanski divan te u dogovoru sa stanovnicima pronađu i povežu odmetnike i njihove jatake kako bi ih se primjereno kaznilo. ${ }^{54}$

\section{Jamstvo i kazne kao mjere protiv hajduka i jataka}

U kojoj su mjeri hajduci zadavali glavobolje osmanskim vlastima i koje je razmjere imala hajdučija još krajem 17. stoljeća govori jedan nedatirani dokument zabilježen u jednom od sidžila blagajskoga kadije (iako se radi o nedatiranu dokumentu, po hercegovačkom valiji koji je izdao bujuruldiju znamo da se radi o kraju 17. stoljeća). Hercegovački valija Sejfulah-paša bio je primoran provesti novačenje vojnika kako bi se uspješno borio protiv hajdučije. Zbog toga je dolazio u Blagaj, gdje su za njega i njegovu svitu, ukupno 41 osobu, morali osigurati smještaj. ${ }^{55}$ Nastojanja vlasti da spriječe hajdučiju često nisu bila uspješna. Zbog ozbiljnosti situacije pribjegavalo se pojedinačnom ili kolektivnom jamčenju, odnosno međusobnom obvezivanju stanovništva da će voditi računa o miru i sigurnosti na svome području, te sprječavati svako razbojstvo. ${ }^{56}$ To je bila jedna od mjera koja je trebala pomoći u zavođenju reda, ali njezina učinkovitost nije uvijek bila na visokoj razini, barem kada je riječ o hajdučiji. Jamčenje ili ćefilema, kako se nekada navodi, često je propisivana i u dokumentima nailazimo na cijele popise stanovništva nekoga mjesta koji jamče jedni za druge. Ovdje izdvajamo samo ona jamčenja koja se izravno odnose na hajduke ili njihove pomagače.

Prvo takvo jamčenje u ovdje obrađenim dokumentima datira iz 1731. godine, kada bosanski valija Ahmed-paša u bujuruldiji od 15. džumada II 1143. (siječanj 1731.) hercegovačkom mutesarifu, kadijama Nevesinja, Blagaja, Stoca, Ljubinja, Cernice, ostataka Novog i

54 Sidžil blagajskog kadije 1697. - 1793., list 36/b.

55 Sidžil blagajskog kadije 1698. - 1779., list 12/a. Prema podatcima koje donosi Bašagić, Sejfulah-paša bio je hercegovačkim namjesnikom od 1106., odnosno 1694. do 1695. godine. Točne datume vezirovanja namjesnika Bašagić ne navodi. S. BAŠAgić-RedžEPAšić, Kratka uputa u prošlost Bosne i Hercegovi$n e$, str. 184. Sejfulah-paša postao je bosanskim namjesnikom 1114., odnosno 1702. godine. Isto, str. 180. Hasandedić je vjerojatno previdio da je Sejfulahpaša bio hercegovačkim valijom od 1694. godine, pa je zbog toga u naslovu prijevoda sidžila stavljena nešto kasnija godina.

56 Više o jamčenju u: Azra Gadžo-Kasumović, "Kolektivno i pojedinačno jamstvo, kefalet-defteri i registracije kefaleta u dokumentima u Bosni osmanskog perioda", u: Anali GHB, 43 (35), Sarajevo, 2014., str. 5-50. 
vojnim zapovjednicima, između ostaloga naređuje da gdje god da se pojave skupine hajduka, dužni su ih pohvatati i zatvoriti. Ukoliko se hajduci opet ne pokore, valija traži da mu se pošalje popis onih koji su za njih jamčili. ${ }^{57} \mathrm{Na}$ temelju tih popisa vlasti su računale da će jamci utjecati na smanjenje hajdučkih prepada, jer su u slučaju njihovih ponovljenih zlodjela jamci prvi bili na udaru. $\mathrm{Na}$ to upućuje i bujuruldija bosanskog valije od 11. safera 1181. (srpanj 1767.) upućena kadijama i vojnim zapovjednicima Hercegovačkog sandžaka u kojoj između ostaloga stoji sljedeće: "Naređuje vam se da u sporazumu sa sudom i posredstvom mubašira izvršite jamčenje svih stanovnika u svim mjestima i da u defter upišete sve generalije o licima koja jamče i za koje se daje jamčenje." ${ }^{58}$ Iako izrijekom nisu spomenuti hajduci, naredba se posredno odnosila i na njih. Popisi su pokrajinskim vlastima davali saznanja o jamcima i onima za koje se jamči te su u slučaju ponovljenih razbojstava mogli reagirati i tražiti točno određenu osobu.

Jamčenja su vršena i među stočarima koji su štitili hajduke i pružali im utočište. U bujuruldiji od 13. muharema 1182. (svibanj 1768.) bosanski valija naređuje kadijama Stoca, Blagaja, Ljubinja, Cernice, Foče te drugim uglednicima da među stočarima s njihovih područja izvrše jamčenje, jer u svoje domove primaju hajduke i daju im hranu. ${ }^{59}$ Znakovito je da se ne naređuje hvatanje ili kažnjavanje stočara, jer je taj naputak bio gotovo redovit u ukazima koji su se izdavali u cilju sprječavanja hajdučije. Hajduci su bježeći pred vlastima ili u potrazi za plijenom prelazili velike udaljenosti, a sigurna mjesta nalazili su upravo u kolibama stočara. To su im čini se bile polazne točke za njihove pljačkaške akcije, na što ukazuje bujuruldija bosanskog valije od 27. rebia II 1190 (lipanj 1776.). Prema tim podatcima vidimo da su hajduci dolazili do pašnjaka Treskavice, Visočice, Kladova Polja i dalje, gdje su se skrivali u stočarskim kolibama. ${ }^{60}$

57 Sidžil blagajskog kadije 1728. - 1732., str. 51.

58 Sidžil mostarskog kadije, fragmenti iz 1179 - 1182. h.g. / 1765 - 1769. g., str. 87. Ista se naredba nalazi u: Sidžil blagajskog suda, fragmenti iz 1141 - 1203 (1729. - 1789.), list 34/a. Zbog nereda i pobuna odmetnici nisu previše marili za jamčenja, nego su i dalje nastavljali s nasiljima. Zbog toga se ponovo u dva navrata džumada I i II 1181. (listopad 1767.) naređuje jamčenje u kadilucima Hercegovačkog sandžaka. Sidžil nevesinjskog kadije 1767 - 1775., str. 74-75.

59 Sidžil blagajskog suda, fragmenti iz 1141 - 1203 (1729. - 1789.), list 31/a.

60 Sidžil blagajskog suda, fragmenti iz 1113 - 1212 (1702 - 1798), list 40/b. 
Jamčenja i druge poduzimane mjere nisu imale uspjeha. Iz bujuruldija koje su izdavane može se iščitati sva uzaludnost toga posla. ${ }^{61}$ Propisivale su hvatanje i kažnjavanje hajduka, te da se njih i njihove jatake veže čvrstim jamstvom, no nema naznaka da je sigurnosna situacija po pitanju hajdučije bila bolja. Različite su bile samo adrese na koje su naredbe upućivane. Jamčenja su omogućavala stanovništvu da se osigura od eventualnih optužbi, no vjerojatno je ono za većinu predstavljalo samo još jednu obvezu i tek privid sigurnosti.

Još u vrijeme Morejskoga rata kršćani su održavali veze s hajducima i obavještavali ih o zbivanjima na osmanskom području, a s njima su surađivali i oni kršćani koji su bili u osmanskoj službi. ${ }^{62}$ Slična prak-

61 Bosanski valija Silahdar Mehmed-paša bujuruldijom od 11. muharema 1184. (svibanj 1770.) upućenoj Sulejman-begu u Trebinju, kadijama Ljubinja, ostatka Novog, Cernice, Nevesinja, ajanima i zabitima naređuje da sve hajduke i odmetnike u njihovim kadilucima pohvataju "žive ili mrtve", te naglašava da hajduke i njihove jatake vežu čvrstim jamstvom. Sidžil nevesinjskog kadije 1767. - 1775., str. 41. Već u rujnu iste godine 28. džumada II 1184., valija naređuje nevesinjskom kadiji, ajanu i zabitu da pohvataju sve hajduke jer su obaviješteni da se neka raja odmetnula, a druga im služi kao jataci. Također navodi "kod ostale raje provedite jamčenje (ćefilemu)". Sidžil nevesinjskog kadije 1767. - 1775., str. 36-37. Tri godine kasnije aga bosanskog odžaka Ali-ćehaja uputio je 12. ševala 1186. (siječanj 1773.) bujuruldiju mostarskom kadiji, serdaru i drugim odgovornima kojom im naređuje da pohvataju hajduke i zlikovce koji se kriju po mostarskim i nevesinjskim selima. Sidžil blagajskog suda, fragmenti iz 1141 - 1203 (1729. - 1789.), list 45/a. Bujuruldija bosanskog valije od 1. rebia II 1191. (svibanj 1777.) kadijama Fojnice, Visokog, Neretve, Konjica, Mostara, Blagaja, Stoca, Prozora i drugima "da očiste zemlju od odmetnika i onih koji po drumovima dočekuju putnike pljačkaju ih i biju". Također se navodi da se opasna mjesta osiguraju pandurima, te da "za sve jatake hajduka treba uzeti jamce (ćefile)". Sidžil blagajskog suda iz 1113 - 1212 (1702. - 1798.), list 50/b.

62 O suradnji kršćana s hajducima svjedoči jedna tužba mostarskih prvaka i drugih stanovnika protiv Ivana, sina Petrova i Jure, sina Marijanova iz Klobuka iz 1685. godine. Navedeni su optuženi da se sastaju s hajducima i "obavještavaju ih o događajima i prave razne smutnje". Sidžili mostarskog kadije, fragmenti iz 1044 - 1207. h. god./1635 - 1793. godine, str. 69. S hajducima je surađivao i Nikola Nonković, koji je u vrijeme Kandijskoga rata bio u osmanskoj službi i radio na osiguravanju reda i mira na osmanskom području Međutim, za Morejskoga rata javlja se kao hajdučki serdar. Vesna Miović-Perić, "Svakodnevnica dubrovačkih pograničnih sela u doba hajdučije (Morejski rat 1684. - 1699.)," u: Anali zavoda za povijesne znanosti Hrvatske akademije znanosti i umjetnosti u Dubrovniku, sv. 35, Dubrovnik, 1997., str. 23, bilj. 15. Osim Nonkovića zanimljiv je i slučaj harambaše Grujice Vukovića iz Perasta, koji je od ljeta 1662., kako to navodi Hrabak, "bio i turski pandurski starešina i hajdučki četovođa protiv turskog režima". B. НraвAK, "Hajdučija u Bosni i Hercegovini...", str. 326. 
sa nastavila se i kasnijih godina. Bez obzira na nevolje koje su hajduci nanosili kršćanima i činjenicu da su i njih jednako napadali, ipak su među njima nalazili svoje pomagače koji su im u zimskim mjesecima osiguravali smještaj i hranu. Pokrajinske su vlasti toga bile svjesne, te su odgovornima u kadilucima slali naredbe i naputke za poduzimanje odgovarajućih mjera protiv jednih i drugih. U gotovo svakoj naredbi ponavlja se da je vojno-administrativnim službenicima glavna dužnost osigurati red i mir, a da bi to postigli, usporedo $s$ jamčenjima propisivalo se hvatanje i kažnjavanje hajduka i njihovih pomagača/jataka. Tako bosanski kajmekam Mehmed, safera 1186. (svibanj 1772.) naređuje da se propisno kazne hajduci i odmetnici koji pljačkaju putnike i stanovništvo u kadilucima Neretva, Konjic, Stolac, ali i njihovi pomagači, kako bi stanovnicima spomenutih kadiluka osigurali mir i sigurnost. ${ }^{63}$ Uostalom, gotovo sve naredbe upućene hercegovačkim kadijama i kapetanima naglašavale su da se s hajducima i njihovim jatacima strogo postupa. Izuzmemo li one naredbe u kojima se nalaže strogo kažnjavanje ili privođenje hajduka živih ili mrtvih, ni u jednom dokumentu nije navedena konkretna kazna za hajdučko djelovanje, osim ponekad naglašavanja da ih se kazni po šerijatu. Za one koji su živi privedeni pred Bosanski divan ne znamo kako su završavali. O njihovoj mogućoj sudbini naznake daje bujuruldija bosanskoga valije Sirri Selim-paše iz 1201. (1787.) godine u kojoj se naređuje da odgovorni u kadilucima Konjic, Mostar, Blagaj, Stolac i Nevesinje "pronađu sve odmetnike i da njihove glave pošalju na bosanski divan". ${ }^{64}$ Znakovito je da je ovdje izostavljena opcija živi, koja se u ranijim dokumentima redovito javljala. Jasno se ističe da se pošalju dokazi o njihovoj smrti. Premda izrijekom hajduci nisu spomenuti, posredno se ova naredba odnosila i na njih. Uzmemo li u obzir probleme koje su stvarali i nesigurnosti kojoj su doprinosili svojim djelovanjem, sigurno je da kazne nisu bile blage i da su privedeni hajduci mogli očekivati najstrožu kaznu. Isto tako, u opasnosti su bili i njihovi jataci, koji su također kažnjavani zbog pomaganja hajducima. Iz dokumenata je nejasno jesu li kazne protiv jataka uistinu primjenjivane, ali to ne znači da se nisu sprovodile u djelo.

Posebnu pozornost privlači činjenica da su jataci unatoč opasnosti od kazne kojom je prijetila osmanska država, ipak ostajali vjerni svojim odmetnutim sunarodnjacima, često rodbini i prijateljima. Mo-

63 Sidžil blagajskog suda, fragmenti iz 1141 - 1203 (1729. - 1789.), list 38/a. 64 Sidžil blagajskog suda, fragmenti iz 1183 - 1201 (1769. - 1787.), list 55/b. 
ramo se zapitati zašto to čine? Zašto svjesno riskiraju ne samo svoj život, nego i sudbinu svojih obitelji? Odgovor na ova i slična pitanja treba tražiti u određenoj bliskosti, krvnoj ili vjerskoj povezanosti s ljudima koji su se odmetnuli od vlasti i koji su u stalnoj smrtnoj opasnosti. Treba imati na umu da se većina hajduka odmetnula zbog teških socijalnih prilika ili učinjene im nepravde. Ostavljali su svoje obitelji svjesno riskirajući život i upuštajući se u jednu avanturu s neizvjesnim završetkom. Isto tako, ne treba zanemariti ni činjenicu da su hajduci usprkos svim razbojstvima koja su činili ipak dobrim dijelom bili kršćani i često su se i fizički obračunavali s vlastima zbog nepravdi koje su im činili. Sama ta činjenica ne opravdava njihova razbojstva, ali je bila dovoljna da steknu određene simpatije kod drugih kršćana koji su ih pomagali i štitili od vlasti. Ponašanje kršćana u velikoj je mjeri bilo uvjetovano njihovim društvenim položajem, te pravima i obvezama prema osmanskoj državi. Kršćani su i otprije, a posebno u 18. stoljeću, klasa nižega reda. Vlasti su im još na početku stoljeća propisivale način odijevanja kako bi se razlikovali od muslimana, ${ }^{65}$ što je uz porezni pritisak i nezadovoljstvo koje su s pravom iskazivali bio dodatni motiv za odmetanje u hajduke ili suradnju $\mathrm{s}$ njima. Stoga ne čudi bujuruldija bosanskoga valije Muhamed-paše od 28. džumada II 1184. (listopad 1770.) upućena nevesinjskom kadiji, ajanu i zabiti u kojoj između ostaloga stoji kako su obaviješteni da se "neka raja odmetnula u hajduke a druga im opet pomaže i služe im kao jataci". ${ }^{66}$ Hajduci, kao i većina raje, u predstavnicima osmanskih vlasti vidi povlašteni sloj, silnike koji ih ponižavaju, zlorabe svoj položaj i izrabljuju raju dovodeći je do krajnjih granica siromaštva. Stoga i ne čudi što mnogi prilaze hajducima ili surađuju s njima. Međutim, da bismo dobili što jasniju sliku o hajducima i njihovim pomagačima, potrebno je razmotriti i način na koji su se hajduci odnosili prema svojim sunarodnjacima. Kako to Miović-Perić navodi, hajduci su terorizirali svoje sunarodnjake i nametali im harač držeći se načela "tko nije s nama, taj je protiv nas". ${ }^{67}$ Pretpostavimo li da su hajduci, vodeći se tim načelom, smatrali neprijateljima sve one koji su odbijali ili htjeli prekinuti suradnju s njima, čak i kad se radilo o članovima njihovih obitelji, suradnja jataka i njihova odanost hajducima dobiva jednu drugu dimenziju. Jataci su vjerojatno smatrali da im veća opasnost prijeti od hajdučke osvete nego kazne kojom je

65 E. Pelidija, Bosanski ejalet..., str. 18.

66 Sidžil nevesinjskog kadije 1767. - 1775., str. 36-37.

67 V. Miović-Perić, Na razmeđu, str. 183-184. 
prijetila osmanska država, tako da su radije (p)ostajali hajdučki pomagači nego im se suprotstavljali.

Unatoč svim nastojanjima i poduzetim mjerama, sigurnosti na putovima nije bilo. $\mathrm{O}$ tome svjedoči i iskaz Petra kalajdžije ${ }^{68}$ od 3. safera 1204. (listopad 1789.), koji je pred kadijom u Zvorniku izjavio kako je tijekom boravka na području Blagajskoga kadiluka njegov otac na putu između Rotimlje, Malog Polja, Hodbine i Vranjevića, ubijen i nestao. Također navodi da je otac uza se imao 600 groša, stoku i kalajdžijski pribor. Drugih pojedinosti o napadačima Petar ne navodi, osim da je i na njega pucano kada je išao tražiti oca. ${ }^{69}$ Njegova izjava ne otkriva ubojicu/e, ali jasno pokazuje da sva nastojanja Porte te brojni dopisi i naređenja u kojima se nalaže zaštita putnika, stanovništva uopće, nisu imali uspjeha. Nesigurnost koja je vladala na putovima u 18. stoljeću prenijet će se i u 19. stoljeće. Podanicima nije preostajalo drugo nego se nositi s time onako kako su najbolje znali, jer ni lokalne ni središnje vlasti nisu uspijevale vratiti mir i sigurnost na putovima.

\section{Zaključak}

Društveno-političke prilike tijekom 18. stoljeća ukazivale su na svu slabost Osmanskoga Carstva, a samovolja lokalnih moćnika, porast redovitih i izvanrednih nameta, te brojne zlouporabe vladajućih struktura utjecali su na sve češće odmetanje u hajduke i otpor protiv vlasti. Muslimansko se stanovništva još u 17. stoljeću diže i buni protiv vlasti, a pogoršanje njihova položaja u 18. stoljeću izazvat će nova nezadovoljstva i nemire. Bune muslimanskoga stanovništva svojom su snagom i razmjerima nadmašivale hajdučiju, ali mjere koje su vlasti poduzimale protiv pobunjenoga stanovništva u konačnici su dovodile do slamanja otpora i smirivanja pobuna. $S$ druge strane, mjere središnjih i pokrajinskih vlasti protiv hajduka i njihovih pomagača nisu imale značajnijega uspjeha, što pokazuju brojni dokumenti u kojima se ukazuje na problem hajdučije i propisuju mjere za njezino sprječavanje.

68 Kalajdžija je zanatlija koji kalajem, odnosno kositrom premazuje bakreno posuđe.

69 Sidžil blagajskoga kadije 1697. - 1793., neoznačeni list između 67/b i 69/b. 
Iako se hajdučija često prikazuje kao borba protiv osmanskoga ugnjetavanja, ovdje prikazana zlodjela, pljačke i nasilja koja su hajduci činili najzornije govore o pravoj prirodi hajdučkoga djelovanja. Hajducima su jednako prilazili kršćani i muslimani, a njihovim žrtvama bili su i bogati i siromašni. Na svaku hajdučku akciju vlasti su primjereno odgovarale, pri čemu se u uputama osmanskim uglednicima redovito naglašavalo da moraju zaštititi narod i raju od nasilja odmetnika, a odgovorne za zlodjela privesti pravdi i primjereno kazniti. Međutim, nastojanja osmanskih vlasti u sprječavanju hajdučije bila su bezuspješna. Na putovima u Hercegovini 18. stoljeća nitko se nije mogao osjećati sigurnim, putnici i trgovci zbog eventualnih napada, hajduci i njihovi pomagači zbog kazni koje su im prijetile za učinjeno. 
Dijana Pinjuh

University of Mostar

Faculty of Humanities and Social

Sciences

E-mail: dijana.pinjuh@ff.sum.ba
Original scientific paper

Received: 26 May 2018

Accepted: 9 April 2019

\section{Brigandage in Herzegovina in the $18^{\text {th }}$ century}

\section{Summary}

Arbitrariness of the local persons in power, which became more evident during the $18^{\text {th }}$ century, conflicts with external forces, increase of regular and special levies as well as abuse of governing structures endangered social position of the population. Tax and feudal pressure increased the number of brigands and robberies and other atrocities became a part of everyday life. Measures undertaken by the Ottoman authorities did not have any effect and bands of brigands disturbed and threatened the security with their activities through the entire $18^{\text {th }}$ century. They had the support and protection among their concealers, whom were equally as brigands threatened by punishment for everything they did. Published and unpublished court transcripts (sidzili) gave various materials about the events in the $18^{\text {th }}$ century and brigandage in Herzegovina and a clearer and more complete picture about brigands and their activities will be made on the basis of those materials.

Keywords: brigands; $18^{\text {th }}$ century; Herzegovina; concealers; brigand activities. 